\title{
KEBERADAAN KAMPUNG SENI JELEKONG DALAM MENUNJANG KEBUTUHAN EKONOMI RUMAH TANGGA
}

\author{
The Existence of Jelekong Art Village in Supporting Household Needs \\ Oleh Irvan Setiawan \\ Balai Pelestarian Sejarah dan Nilai Tradisional Bandung \\ Jln. Cinambo No. 136 Ujungberung Bandung \\ Email: kamaliasetiawan@yahoo.co.id
}

Naskah Diterima: 23 April 2012

Naskah Disetujui: 23 Mei 2012

\begin{abstract}
ABSTRAK
Kampung Seni Jelekong telah lama menapakkan kiprahnya dalam bidang industri kreatif berbasis kebudayaan. Hasil yang dicapai adalah ketenaran Jelekong hingga ke mancanegara sebagai kelurahan di Kecamatan Baleendah Kabupaten Bandung yang memproduksi lukisan dan kerajinan wayang golek. Berdasarkan pengalaman tersebut, Pemerintah Daerah Kabupaten Bandung memberikan predikat Desa Wisata melalui SK Nomor 556.42/Kop.71 - Dispopar/2011. Pengalaman yang telah dicapai sebagai kampung seni tentunya harus melalui proses yang cukup panjang. Di samping itu juga ada kiat-kiat tertentu yang menjadi pedoman mereka untuk tetap menekuni industri berbasis kebudayaan tersebut. Kiat-kiat yang tentunya harus memperhatikan unsur hobi, kemahiran, dan sektor pendapatan yang mereka terima selama bekerja sebagai seniman di Kelurahan Jelekong. Penelitian yang menggunakan metode deskripsi dengan pendekatan kualitatif ini menemukan adanya aspek ketekunan, strategi pemasaran, dan pola pembagian kerja yang bervariasi. Aspek ketekunan dicapai oleh para pelopor seni yang secara intensif mengajarkan pada warga Jelekong untuk berkecimpung dan mencari nafkah melalui pemberdayaan produk seni. Strategi pemasaran menuntut kreativitas mereka semaksimal mungkin baik melalui modifikasi karya seni maupun memperbanyak relasi mulai dari strategi door to door hingga membuka galeri seni. Pola pembagian kerja yang fleksibel, yaitu segi kualitas dan kuantitas seniman menjadi tolak ukur besaran pendapatan yang mereka terima untuk nantinya digunakan mencukupi kebutuhan mereka sehari-hari.
\end{abstract}

Kata kunci: Kampung Seni Jelekong, kebutuhan rumah tangga.

\begin{abstract}
Jelekong has been famous for its creativity in culture-based industry, especially in producing wayang golek paintings and handicrafts. It was awarded Desa Wisata (Village of Tourism) by the government of Regency of Bandung in 2011. This village has certain tips that guide them running the business, tips that combine many elements like hobby, skill, and income that they receive during they are working as artists in the village. By conducting descriptive method and qualitative approach, the author finds that
\end{abstract}


combination of persistence, marketing strategy and division of work are indirect factors for the artists to rely on art as their main income.

\section{Keywords: art village of Jelekong, household needs}

\section{A. PENDAHULUAN}

Sapta Dharma Pariwisata, Seni dan Budaya adalah sebuah motto Kementerian Kebudayaan dan Pariwisata. Dalam poin 3 Sapta Dharma disebutkan bahwa pariwisata, seni, dan budaya berperan dalam pemberdayaan ekonomi rakyat. Poin tersebut memiliki keterkaitan erat dengan visi pemberdayaan seni budaya dan pariwisata, yaitu menjadikan karya seni dan budaya bangsa Indonesia lebih terbina secara intensif, terpelihara dan dikembangkan, agar berperan lebih strategis dalam pembangunan perekonomian nasional secara keseluruhan. Dengan kata lain, melalui seni budaya dan pariwisata - terutama kesenian - setidaknya dapat menjadi sebuah mata pencaharian bagi para seniman selain mempersembahkan sebuah karya seni kepada masyarakat. Sebelum adanya motto dan visi tersebut, telah lama sebenarnya sebuah karya seni berperan ganda dalam menyajikan sebuah kesenian kepada masyarakat sekaligus menjadi salah satu sumber mata pencaharian bagi para seniman itu sendiri. Contoh jelas terutama di Kota Bandung - adalah topeng monyet dan kuda lumping yang saat ini marak bermunculan di perempatan jalan. Mereka mempertontonkan sebuah kesenian tradisional sambil mengharap belas kasihan para pengemudi untuk melempar sedikit coin yang akan digunakan sebagai "penyambung hidup" mereka. Apakah mereka mempunyai komunitas? Sesama rekan seprofesi, mereka setidaknya akan meluangkan waktu untuk berkumpul dan berbagi pengalaman seni.

Wadah, perkumpulan, ataupun organisasi seniman saat ini secara umum memang telah banyak tersebar di berbagai daerah. Walaupun demikian, apakah keberadaan kampung seni juga sama banyaknya dengan perkumpulan, wadah, ataupun organisasi? Secara gamblang dapat dikatakan bahwa masih jarang terdengar adanya keberadaan kampung seni karena seni itu sendiri pada saat ini dapat dikatakan bukan menjadi sebuah pekerjaan utama. Berbeda halnya dengan perumahan atau komplek dinas sebagai sebuah lokasi yang dihuni masyarakat dengan profesi pekerjaan yang sama.

Pengertian kampung seni pada sebagian masyarakat awam mengacu pada sebuah komunitas yang sejak awal berdirinya menjadi tempat para seniman melakukan aktivitas baik rumah tangga maupun pekerjaan. Anggapan tersebut memang benar adanya karena dari awal mula berdirinya kampung seni menjadi semacam lokasi para seniman untuk menghasilkan sebuah karya seni yang memberi manfaat tidak saja bagi para pecinta seni tetapi juga bagi para seniman itu sendiri dalam memenuhi kebutuhan hidup mereka sehari-hari.

Walaupun terdengar seperti menjanjikan, sebuah kampung seni dalam memberdayakan seni dan perekonomian para seniman, namun dalam kenyataannya banyak dari seniman malah beralih profesi karena kebutuhan ekonomi mereka tidak cukup dari hanya mengandalkan pekerjaan seni semata. Kebanyakan mereka memilih pekerjaan menjadi wiraswasta ataupun bekerja pada sebuah lembaga atau perusahaan. Walaupun pada akhirnya jiwa seni mereka tetap tidak hilang dan bukan tidak mungkin pada suatu saat mereka kembali ke daerah mereka untuk melanjutkan kiprah mereka di bidang seni untuk dijadikan sebagai bagian dari penunjang ekonomi seniman beserta keluarganya.

Jelekong, sebuah kampung seni di Kabupaten Bandung, adalah sebuah daerah 
yang telah lama berdiri dan dihuni oleh masyarakat dengan satu profesi pekerjaan, yaitu seniman. Hingga saat ini Kampung Seni Jelekong masih eksis dalam mempertahankan seni sebagai sebuah pekerjaan. Apa kiat-kiat mereka dalam mempertahankan seni sebagai sebuah pekerjaan dan seberapa besar sumbangan kesenian dalam memenuhi kebutuhan ekonomi mereka? Sebuah pertanyaan yang sangat menarik untuk dikaji dan ditelusuri hingga menemukan jawaban yang nantinya diharapkan berguna bagi instansi terkait dalam menyusun kebijakan yang erat kaitannya dengan seni, budaya, dan pariwisata.

Maksud penelitian ini adalah menelusuri, mendeskripsikan, dan menganalisis upaya yang telah dilakukan warga masyarakat di Kampung Jelekong dalam mempertahankan seni sebagai sebuah pekerjaan dan seberapa besar sumbangan kesenian dalam memenuhi kebutuhan ekonomi mereka. Tujuan penelitian adalah untuk memperoleh data yang komprehensif berikut analisa data yang terkait dengan eksistensi Kampung Seni Jelekong dalam menunjang kebutuhan ekonomi rumah tangga.

Jenis penelitian yang dilakukan adalah deskriptif dengan mengambil pendekatan kualitatif. Dengan demikian dapat dikatakan bahwa penelitian ini akan menggambarkan secara terperinci mengenai kehidupan warga di Kampung Seni Jelekong dalam upaya mereka untuk menjadikan seni sebagai sebuah pekerjaan yang dapat digunakan sebagai salah satu sumber pendapatan untuk pemenuhan kebutuhan ekonomi. Sementara pendekatan kualitatif dalam penelitian ini digunakan untuk mendapatkan data primer berdasarkan pengamatan dan wawancara. Sementara data sekunder juga akan dicari dengan mengambil data dari buku, skripsi, disertasi, majalah, suratkabar, dan sumber lainnya yang biasa diperoleh di perpustakaan.
Pencarian data primer dilakukan dengan menggunakan metode observasi partisipasi dan non-partisipasi. Teknik wawancara digunakan dengan menggunakan teknik verbal (pembicaraan langsung) maupun dengan menggunakan pedoman wawancara yang telah disiapkan sebelumnya. Data dari hasil wawancara disimpan dalam tape recorder yang sekaligus sebagai bukti akurat dari hasil tulisan yang dipaparkan dalam hasil penelitian. Penggunaan tape recorder juga untuk mengurangi tingkat kesalahan interpretasi dengan cara replay apabila ada informasi yang kurang jelas dari pembicaraan dengan informan.

Terkait dengan data kualitatif dari hasil wawancara maka analisa data yang dilakukan pun akan menggunakan analisa kualitatif. Tahap pertama teknik analisa kualitatif adalah menghimpun data dalam sebuah wadah yang bernama taxonomy data, yaitu himpunan data yang telah dipilah berdasarkan beberapa kategori data. Tujuannya adalah untuk mempermudah penggambaran data sekaligus memilah apakah data tersebut tergolong primer atau sekunder. Dengan demikian dapat dikatakan bahwa taxonomy data sangat berguna untuk menjaga data dari kesalahan penulisan dan penempatan data dalam paparan hasil penelitian.

\section{B. HASIL DAN BAHASAN}

\section{Gambaran Umum Lokasi Penelitian}

Kelurahan Jelekong merupakan bagian dari wilayah Kecamatan Baleendah Kabupaten Bandung. Adapun batasan administrasi Kelurahan Jelekong adalah sebagai berikut:

- Di sebelah timur: Kelurahan Wargamekar Kecamatan Baleendah.

- Di sebelah barat: Kelurahan Manggahang Kecamatan Baleendah.

- Di sebelah utara: Desa Bojongsari Kecamatan Bojongsoang. 
- Di sebelah selatan: Desa Patrolsari Kecamatan Arjasari.

Berdasarkan data Monografi Kelurahan Jelekong tahun 2011, penduduk Kelurahan Jelekong berjumlah 21.006 jiwa atau 5.466 KK. Mereka memiliki jenis mata pencaharian beranekaragam dan sebagian besar adalah sebagai petani, buruh swasta, pedagang, dan perajin. Sementara itu, mengenai besaran penghasilan, para pemilik galeri memiliki jumlah pendapatan tertinggi yang kemudian disusul oleh pendapatan yang diperoleh para pegawai negeri, pegawai swasta, pelukis, dan buruh tani.

Mengenai tingkat pendidikan, penduduk Kelurahan Jelekong berdasarkan data Monografi Kelurahan Jelekong tahun 2009, lulusan pendidikan terbanyak adalah pada tingkat pendidikan keagamaan (5500 orang) kemudian diikuti oleh lulusan SD yang berjumlah 4300 orang, SLTA (2400 orang), SLTP (2215 orang), akademi/D1D3 (2050 orang), kursus/ketrampilan (500 orang), madrasah (380 orang), sarjana S1S3 (180 orang), pondok pesantren (15 orang), dan SLB (2 orang). Berdasarkan data tersebut dapat dikatakan bahwa sebagian besar warga Jelekong sudah dapat mengikuti anjuran wajib belajar 9 tahun.

\section{Pembuatan Produk Seni Jelekong}

Pelukis di Kelurahan Jelekong menempati beberapa kampung, yaitu Giriharja (RW 01), Cikadu (RW 02), Nanggerang (RW 03, 09, 11), dan Batu Gajah (RW 04).

Ada dua produk seni Kelurahan Jelekong, yaitu wayang golek dan lukisan. Untuk menjadi sebuah karya seni yang siap jual tentu membutuhkan proses mulai dari pengadaan bahan baku yang kemudian diolah melalui beberapa proses. Proses pembuatan sebuah produk seni lukis dengan produk seni wayang golek memiliki perbedaan mendasar. Hal ini disebabkan materi yang digunakan serta jenis karya seni yang berbeda, yaitu antara seni lukis dengan seni ukir atau pahat.

\section{a. Pembuatan Karya Seni Lukis}

Menurut Ayat (1999: 112 - 118), proses untuk menjadi sebuah gambar yang siap dijual terdiri dari beberapa tahap. Tahap pertama adalah pengadaan bahan baku, yaitu tinta cetak berbagai warna, palet (tempat cat), pisau palet, kain mori (untuk bahan kanvas), kuas berbagai ukuran, dan terpentin. Tinta cat yang digunakan biasanya merk peoni. Alternatif bahan biasanya ada pada kain kanvas, yaitu selain menggunakan kain mori dapat juga menggunakan kain dari karung tepung terigu. Alternatif lainnya dalam proses melukis adalah dengan menggunakan sponge yang mulai tenar tahun 1990. Ketenaran penggunaan sponge bertahan hingga saat ini. Teknik sponge yang dipadukan dengan sapuan pisau palet sangat cocok untuk melukis pemandangan.

Proses pembuatan kain kanvas adalah melapisi dengan tepung kanji. Caranya tepung kanji sedikit demi sedikit dimasukkan dalam air panas hingga mencapai tingkat kekentalan yang diinginkan. Setelah dirasa sesuai maka sedikit demi sedikit cairan tepung kanji tersebut dilabur pada kain mori yang telah dibentangkan terlebih dahulu. Proses pelaburan adalah dengan menggunakan kuas besar secara merata lalu dijemur di bawah terik matahari. Apabila cuaca tidak memungkinkan, proses penjemuran dilakukan dengan cara menjerang di atas tungku. Proses ini jelas memakan biaya bahan bakar serta hasilnya lebih jelek daripada penjemuran di bawah sinar matahari.

Setelah kanvas selesai dibuat, proses selanjutnya adalah ngadasaran (dasar). Sesuai dengan istilah tersebut, proses ini dilakukan dengan menggambar pola dasar berupa pembagian besaran ruangan gambar. Proses ini tidak menggunakan alat tulis sebagaimana gambar sketch atau pola biasa tetapi menggunakan kuas besar dengan menggunakan warna dasar biru muda, hitam, dan abu-abu. Setelah gambar dasar tersebut selesai kemudian dikering- 
kan di bawah sinar matahari selama lebih kurang 30 menit.

Proses selanjutnya adalah mengolah gambar dasar menjadi gambar jadi. Bahan yang digunakan adalah pisau palet dan cat. Penggunaan pisau palet ini dapat dikatakan mendominasi peralatan yang digunakan untuk melukis karena goresan dari pisau palet membuat alur tegas dari setiap detail lukisan. Ketegasan warna ini memang menjadi ciri lukisan para pelukis Jelekong yang banyak mengambil tema pemandangan ataupun gambar lain yang sesuai dengan kehendak konsumen. Pengaburan antarwarna memang kurang begitu diminati konsumen yang rata-rata menginginkan ketegasan warna lukisan.

Proses terakhir adalah menambahkan sentuhan akhir untuk memperjelas subyek dari lukisan tersebut. Proses ini dilakukan pelukis dengan harapan agar orang yang melihat dapat langsung tertuju pada subyek lukisan tersebut untuk kemudian mencermati gambar di sekitarnya dan berakhir pada ketertarikan membeli lukisan tersebut.

Aliran lukis para pelukis Jelekong yang sebagian besar bersifat naturalis mengarahkan tema gambar mengesankan unsur keseimbangan warna yang meniru pada obyek sebenarnya berikut efek gerak seperti ranting yang tertiup angin ataupun kilatan cahaya sinar matahari. Begitu juga obyek benda yang menjadi tema lukisan. Sebuah bunga akan lebih menarik bila diberi efek sinar matahari serta warna bunga dalam vas yang kontras membuat mata langsung tertuju pada lukisan tersebut. Pola demikian juga diterapkan pada jenis gambar lainnya seperti pacuan kuda, buah-buahan, kereta kencana, ikan koi, dan adu ayam.

Mereka bekerja dalam sebuah ruangan yang mereka sebut dengan istilah studio berukuran sekitar 4 x 5 meter. Tipe ruangan studio ini adalah dinding dengan atap yang terbuka., tujuannya agar bau cat tidak terkungkung dalam ruangan. Ukuran
4 x 5 meter digunakan maksimal oleh 4 orang. Sesuai dengan jiwa seorang seniman yang kurang begitu memperhatikan kebersihan tatkala saat melukis, kondisi ruangan terlihat berantakan dan penuh dengan kotoran cat, dan abu rokok.

Pekerjaan dilakukan tidak setiap hari. Biasanya hari Minggu atau hari besar, mereka meliburkan diri. Jam kerja biasa dilakukan mulai pagi hingga sore hari. Walaupun demikian, apabila ada order lukis yang cukup banyak, terkadang mereka melukis pada malam hari dengan tentunya diberi penerangan yang memadai agar kualitas warna sama apabila dilihat pada siang hari.

\section{b. Pembuatan Karya Seni Wayang Golek}

Pembuatan wayang golek memerlukan bahan baku dan proses pengerjaan. Bahan utama untuk membuat wayang golek adalah kayu. Jenis kayu yang biasa dipakai adalah kayu lame (kayu mahoni) atau albasia. Peralatan yang digunakan khusus untuk pengerjaan kayu tersebut tergolong sangat sederhana di antaranya bedog (golok), gergaji, kampak besar, kampak kecil, dan pisau raut (pisau ukir). Penggunaan kayu lebih mengutamakan jenis kayu lame dan albasia karena kayu tersebut tergolong bagus dari segi warna dan mudah dibentuk. Terlebih lagi, kayu lame tergolong tahan terhadap perubahan cuaca baik dingin ataupun panas. Acuan kayu jenis ini adalah untuk mengantisipasi terutama apabila pembeli dari luar negeri (negara 4 musim).

Proses awal pembuatan wayang adalah membuat gambar wajah terlebih dahulu secara detail. Membuat wayang golek tidaklah mudah karena tergantung dari detail wayang itu sendiri. Semakin rumit detail karakter wayang maka akan semakin lama proses pembuatan sebuah wayang. Bagian yang dianggap cukup rumit adalah pada bagian mahkota. Hal ini disebabkan bentuk mahkota secara tidak langsung menjadi ciri tokoh wayang tersebut. Proses pembuatan kepala dan 
mahkota membutuhkan alat pisau ukir dan ampelas. Bentuk dasar kepala diampelas terlebih dahulu baru kemudian diukir dengan menggunakan pisau ukir.

Dalam proses menggambar detail wayang, seorang seniman wayang harus memperhatikan 3 bentuk pakem. Menurut Nana Suryana, pakem diartikan sebagai cerita wayang asli atau pedoman bagi suatu pertunjukan wayang. Pakem memuat dialog lengkap termasuk cara pengucapan (antawacana), suluk (bentuk), gending (musik), dan sabet (cara dalang memainkan wayang). Selain itu, pakem golek juga meliputi cara pembuatan karakter tokoh Wayang Golek. ${ }^{1}$ Tiga penokohan tersebut adalah: Pakem Golek Satria, Pakem Golek Ponggawa, dan Pakem Golek Buta. Dari ketiga pakem penokohan tersebut kemudian tercipta raut muka wayang golek yang terdiri dari raut peranan, raut tampang, dan raut wanda. Keseluruhan raut muka tersebut dicirikan terutama pada bentuk mata, hidung, dan mulut.

Setelah selesai pembuatan kepala kemudian dilanjutkan dengan pembuatan badan dan tangan. Tangan harus dibuat terlebih dahulu karena turut menentukan antara porsi badan dan besaran kepala wayang golek.

Setelah pembuatan kepala, badan, dan tangan kemudian dilanjutkan dengan proses pendempulan. Selesai didempul kemudian dijemur di bawah sinar matahari hingga kering. Setelah kering kemudian diampelas agar permukaan menjadi halus.

Setelah pendempulan wayang golek selesai dikerjakan, proses selanjutnya adalah pengecatan. Sebelum diwarnai atau dicat, wayang golek diberi arsiran terlebih dahulu untuk menentukan bagian mana

${ }^{1}$ Lebih lanjut lihat "Pengertian Pakem, Raut Muka dan Wanda pada Wayang Golek", dalam http://www.kalangsunda.net/apps/forums/topic s/show/3183744-pengertian-pakem-raut-dan tanggal 9 Agustus 2010. akan diberi warna apa. Sementara pada bagian hiasannya, dibuat dengan cara dipulas.

Bahan yang digunakan adalah cat terutama dari bahan cat duko, yaitu cat yang biasa digunakan untuk mengecat mobil. Penggunaan cat jenis ini dianggap lebih menguntungkan karena selain lebih cepat kering, juga daya tahan, tingkat kecerahan dan sifat cat yang cepat merata ke seluruh permukaan wayang golek. Proses pengeringan harus dilakukan pada cuaca yang tepat, karena proses pengeringan tidak boleh terlalu panas sehingga cat tidak mengelupas.

Proses pembuatan selanjutnya adalah membuat tuding (pegangan wayang golek) dengan menggunakan bambu sebagai bahan utama. Tuding digunakan sebagai pegangan dalang pada saat memainkan golek, yaitu alat untuk menggerakkan bagian tangan golek dan untuk menancapkan golek di atas alas gebog 'batang pisang'.

Setelah selesai pembuatan anggota tubuh wayang golek kemudian dilanjutkan dengan pembuatan pakaian. Bahan untuk membuat pakaian biasanya menggunakan kain tenun berwarna-warni atau kain beludru yang dibuat dengan cara dijahit. Pakaian ini kemudian diberi manik-manik dari bahan mute plastik yang mengkilat.

Proses pembuatan wayang golek secara keseluruhan biasanya dikerjakan oleh beberapa orang. Dengan demikian, beberapa tahapan di atas dapat dikerjakan secara bersamaan seperti pembuatan tangan, badan, kepala, dan pakaian wayang golek. Sementara itu, yang tidak dapat dikerjakan bersamaan adalah pada bagian pendempulan dan pengecatan karena bagian pengecatan harus menunggu sampai proses pendempulan selesai.

Untuk wayang yang detailnya tidak terlalu rumit, para seniman dapat membuat 3 kepala wayang per hari, sedangkan untuk wayang dengan detail yang rumit bisa membutuhkan waktu hingga 2 hari per satu 
kepala dan untuk menyelesaikan satu buah wayang dengan segala bentuk dan komplit dengan asesorisnya dibutuhkan waktu kurang lebih 3 hari.

\section{Keberadaan Kampung Seni dalam Menunjang Kebutuhan Ekonomi Rumah Tangga}

Sangat naif apabila menganggap sebuah karya seni dibuat tanpa persiapan terlebih dahulu. Mereka yang berprofesi sebagai seniman berupaya keras agar karya seni mereka minimal mengandung unsur keindahan dan kecukupan estetika hingga mengundang mata untuk melirik hasil karya seni yang mereka buat. Unsur estetika dan keindahan merupakan modal awal bagi seniman yang harus dimiliki melalui beberapa macam cara. Transmisi kesenian memang mutlak terjadi dalam hal ini. Pengetahuan formal untuk menjadi seniman bukan sebuah aturan mutlak yang harus dimiliki karena ada proses transmisi kesenian lainnya yang tidak kalah penting yaitu proses pewarisan kesenian. Anderson (1965) dalam Suryatna (1999: 28) mengatakan:

"Usaha mewariskan kesenian dapat dipandang juga sebagai bentuk pemenuhan kebutuhan integratif yang dilakukan secara terus menerus, baik sadar maupun tidak sadar serta terjalinnya hubungan antara fihak yang belajar dan fihak yang mengajar secara aktif. Usaha pewarisan kesenian ini berarti mempunyai kaitan dengan usaha melestarikan norma, nilai pendidikan dan aspek kebudayaan lainnya."

Istilah "kampung seni" telah menjadi predikat yang sangat melekat pada Kelurahan Jelekong. Secara kasat mata, memang, di dalam kampung seni tersebut jelas terlihat berbagai kegiatan seni berlangsung setiap harinya, mulai dari proses sket lukisan, pewarnaan, maupun penjemuran hasi lukisan. Begitu juga halnya dengan kerajinan wayang golek yang kerap diisi dengan bunyi pukulan palu pada pahat ukir serta bau cat yang cukup menyengat saat proses pengecatan wayang golek. Ataupun pada saat tertentu diwarnai dengan atraksi pertunjukan wayang golek yang tergolong atraktif serta mengundang minat masyarakat untuk melihat dan mencerna jalan cerita pertunjukan tersebut.

Masyarakat atau pengunjung yang datang dapat dengan bebas untuk melihat proses produksi ataupun membeli produk yang dihasilkan dari para seniman Jelekong. Setelah puas dengan suguhan yang ditampilkan kampung seni tersebut, pengunjung pulang dan menceritakan apa yang dilihat pada kerabat atau tetangga bahwa di Kampung Jelekong banyak dilakukan atraksi seni yang sangat menarik dan dapat membeli barang seni tersebut sebagai oleh-oleh khas Kampung Jelekong.

Pandangan sekilas tersebut memang menggambarkan Kampung Seni Jelekong merupakan sebuah kampung yang diisi dengan berbagai aktifitas seni. Namun demikian, apabila dilihat dari karakteristik Kampung Jelekong, akan terlihat bahwa kegiatan yang ada di sana akan memiliki persamaan dengan proses produksi dari sebuah industri seni.

Antara seni dan industri sebenarnya memiliki perbedaan ideologis. Seni amat kental dengan sifat ekspresi dan imajinasi seseorang yang dituangkan dalam sebuah karya. Dua sifat tersebut tidak mementingkan faktor untung rugi karena hal itu akan merusak proses seni yang sedang dibuat. Sementara itu, industri memiliki prinsip keuntungan dari benda yang telah dihasilkan. Definisi lebih jauh lagi adalah seperti yang diungkapkan oleh Abdurachmat (1998: 28), yang mengatakan bahwa:

"Industri memiliki arti luas dan sempit. Dalam arti sempit meliputi segala usaha dan kegiatan yang sifatnya mengubah bahan mentah menjadi barang jadi atau barang setengah jadi. Sedangkan industri dalam arti luas mencakup pengertian 
semua kegiatan di bidang ekonomi yang produktif."

Menyinggung masalah ekonomi dalam industri berarti mengharuskan barang hasil produksi memberi nilai tambah setelah diolah dari barang mentah menjadi barang jadi yang siap dipasarkan. Hal ini diungkapkan oleh Sandi (1985: 148) yang menyatakan bahwa:

"Industri adalah usaha untuk memproduksi barang jadi dari bahan baku atau bahan mentah melalui proses penggarapan dalam jumlah besar sehingga barang jadi bisa diperoleh dengan harga satuan serendah mungkin tetapi tetap dengan mutu yang tinggi."

Dengan demikian, dapat dikatakan bahwa untuk menjadikan sebuah karya seni menjadi salah satu komoditi industri diwajibkan untuk melalui proses produksi yang dihitung berdasarkan azas rugi laba tanpa mengurangi kualitas karya seni tersebut.

Kedua hal tersebut (seni dan industri) sebenarnya dapat bergandengan tangan untuk menghasilkan sebuah karya yang dapat diperjualbelikan dengan beberapa persyaratan tentunya. Persyaratan sebuah unsur seni sangat mudah karena seni adalah sebuah proses pemikiran yang dituangkan dengan menggunakan peralatan pembantu. Ketiadaan peralatan dapat ditanggulangi oleh pihak penyedia apabila sebuah kesenian memang berniat untuk menjadi sebuah komoditi industri. Abdurachmat dan Maryani (1998: 30-31) membagi jenis industri menjadi 4 kelompok besar, yaitu: a. Aneka Industri dan Kerajinan, b. Industri Logam dan Elektronika, c. Industri Kimia, dan d. Industri Sedang dan Tekstil.

Melihat dari klasifikasi yang ditawarkan oleh Abdurachmat dan Maryani di atas, industri seni lukis dan wayang golek jelas termasuk dalam aneka industri dan kerajinan. Walaupun demikian, kelompok industri pertama tersebut secara umum sering dimasukkan dalam skala usaha industri yang tergolong kecil atau dapat pula disebut dengan istilah "ekonomi kreatif". Lebih spesifik lagi dalam pembagian skala (jumlah produksi) suatu industri adalah seperti yang diungkapkan oleh Abdurachmat dan Maryani (1998: 30-31) yang membagi dua hasil produksi dalam sebuah industri yaitu industri besar dan industri kecil. Tentunya industri seni yang berada di Kelurahan Jelekong jelas termasuk dalam kategori industri kecil. Sementara itu, klasifikasi jenis produksi yang menjadi andalan masyarakat Jelekong masuk dalam kelompok aneka industri dan kerajinan.

Lokasi "industri seni" di Kelurahan Jelekong adalah spesifik. Artinya, lokasi yang digunakan untuk menghasilkan produk lukisan dan wayang golek bercampur atau menyatu dengan pemukiman warga. Hal ini memang menjadi ciri khas industri rumahan yang menjadikan beberapa ruangan atau halaman rumah digunakan sebagai lokasi proses produksi. Priasukmana (2001: 38) menyebutkan pola, proses dan tipe pengelola lokasi industri tersebut adalah dari jenis tipe terstruktur (spontaneus), yaitu proses kemunculan sebuah industri atau usaha yang hampir bersamaan dengan kemunculan dari perumahan atau pemukiman itu sendiri.

Lokasi industri yang menyatu dengan tempat tinggal atau perumahan, di samping memberikan keuntungan berupa pengawasan proses produksi dan jam kerja fleksibel (bisa dilakukan di luar jam kerja pada umumnya), namun pada sisi lain keberadaan industri tersebut juga harus mengikuti aturan sosial atau kebiasaan yang ada dalam lingkungan tersebut. Contoh kecilnya adalah penghentian proses produksi apabila pemilik industri (lukis dan wayang golek) tersebut mengadakan hajatan. Tentu saja proses produksi akan terganggu karena lokasinya digunakan untuk tempat pelaksanaan hajatan. Selain itu, tata ruang lokasi industri harus 
mengikuti tata ruang sebuah rumah tangga. Artinya, susunan ruangan industri tentunya memprioritaskan susunan ruangan rumah tangga terlebih dahulu. Memang, sebuah rumah tangga, ataupun sebuah wilayah berpenduduk, tentunya harus memiliki sistem peraturan, nilai dan norma, serta didukung oleh kelengkapan sarana fisik. Dengan adanya seluruh sektor tersebut maka akan memudahkan penduduk untuk dapat melakukan berbagai kegiatan baik dalam pemenuhan kebutuhan keluarga ataupun pekerjaan mereka. Hal ini akan menjadi sulit dilaksanakan apabila luas tanah serta dana yang kurang mencukupi akan mengakibatkan adanya benturan prioritas penataan ruang antara kebutuhan ruangan industri dengan dengan ruangan rumah tangga.

Pemenuhan akan kebutuhan "ruang" sebagai tempat bernaung atau mencari nafkah, bukan berarti satu-satunya faktor untuk menentukan tingkat kesejahteraan seorang seniman. Adapun ukuran untuk menentukan tingkat kesejahteraan sebuah keluarga atau masyarakat menurut Soesanto dalam Andarina (2006:31) berpedoman pada pemenuhan: 1) Pendidikan; 2) Kesehatan; 3) Ketertiban sosial; 4) Milik pribadi yang diijinkan oleh masyarakat; dan 5) Kesempatan rekreasi dan menggunakan waktu senggang. Pemenuhan lima kebutuhan tersebut dapat terlaksana apabila ada penghasilan yang cukup sehingga sebuah keluarga atau masyarakat dapat dikatakan sejahtera.

Seni yang menjadi andalan mata pencaharian Kelurahan Jelekong memberikan sumbangsih yang cukup berarti bagi pemenuhan kebutuhan pokok seniman tersebut. Meskipun ada klasifikasi jenis pekerjaan yang tentunya berimbas pada jumlah penghasilan yang mereka terima. Para pelukis memiliki jumlah pendapatan yang berbeda sesuai dengan jenis pekerjaan yang mereka lakukan. Seperti halnya dengan mata pencaharian sebagai petani, lukisan sebagai mata dagangan, untuk sampai ke tangan pembeli bisa melalui beberapa cara. Pelukis dapat langsung berinteraksi dan menjual hasil lukisannya ke tangan pembeli. Pola tersebut diartikan bahwa sang pelukis tersebut memiliki dua profesi, yaitu pembuat dan penjual. Cara penjualan biasa dilakukan dengan istilah door to door. Mereka menjajakan lukisannya terutama di daerah pemukiman penduduk kelas menengah ataupun memajang di pinggir jalan. Jenis pelukis dari tipe ini jelas memiliki keuntungan cukup besar karena selain hasil karya mereka sendiri, ditambah dengan biaya pigura yang tidak begitu mahal, sebuah lukisan yang tadinya berharga sekitar 9.000 rupiah -10.000 rupiah dapat mampu dijual dengan keuntungan 50.000 rupiah. Walaupun demikian, keuntungan tersebut adalah relatif karena harus dipotong biaya operasional yang cukup mahal seperti ongkos transportasi dan konsumsi selama menjajakan lukisannya.

Ada juga pelukis yang hanya berprofesi sebagai pembuat saja, sementara penjualan dilakukan oleh pihak ketiga. Biasanya penjual yang dimaksud adalah pemborong yang telah memiliki saluransaluran penjualan di berbagai tempat. Mereka dapat dikatakan pula sebagai pengepul, yaitu tempat para pelukis menaruh hasil lukisannya pada seseorang untuk kemudian dijual kembali. Terkadang, sang pengepul mengalami hambatan saluran penjualan karena permintaan berkurang. Hal ini tentu saja akan berimbas pada proses pembayaran pada para pelukis yang telah menaruh hasil lukisan padanya.

Jenis lainnya adalah pelukis hanya mengandalkan skill tanpa ada peralatan yang dimilikinya. Penyediaan peralatan lukis diperoleh langsung dari pemilik modal. Dengan demikian, mereka (pelukis) dapat disamakan dengan pekerja atau buruh. Pembagian kerja tersebut memiliki kesamaan dengan Suryatna (1999: 109). Beliau membagi tipe pelukis menjadi tiga 
tipe, yaitu: tipe pelukis pengusaha, pelukis pedagang, dan pelukis buruh. ${ }^{2}$

Imbas dari perbedaan tipe pekerja tersebut mengakibatkan jumlah penghasilan juga turut berbeda pula. Pengusaha lukisan jelas memiliki penghasilan lebih besar daripada pedagang dan pembuat (buruh) lukisan. Dari hasil penelitian Suryatna (1999: 111) diketahui bahwa pada tahun 1999 untuk setiap lukisan, seorang buruh gambar akan mendapat penghasilan 1.200 rupiah. Rata-rata lukisan yang dibuatnya bisa sampai 10 buah atau lebih. Artinya, ia akan memperoleh penghasilan sebesar 12.000 rupiah bahkan lebih. Walaupun demikian, jumlah sebesar itu tentunya akan dikurangi dengan biaya konsumsi dan snack seperti rokok dan kopi yang diambil dari jumlah penghasilan mereka. Apabila dibandingkan dengan harga pada masa itu, sebungkus rokok merk Kansas - misalnya - berharga 3.500 rupiah, maka seorang buruh lukis harus menghasilkan minimal 3 buah lukisan untuk membeli rokok tersebut. Perbandingan ini tentu bukan hal yang mutlak karena mereka dapat saja membeli rokok yang lebih murah untuk mengirit biaya. Walaupun sudah mengirit dari berbagai sisi, penghasilan buruh lukis tersebut dapat dianggap masih kurang mencukupi karena krisis moneter. Perihal krisis moneter, Tarmidi (1998: 1) mengungkapkan bahwa krisis moneter telah terjadi sejak awal Juli 1997 dimana harga barang impor lebih murah dari

\footnotetext{
2 Tipe pengusaha adalah mereka yang memiliki dana cukup besar yang digunakan untuk "membuka usaha" lukisan. Ongkos menjadi faktor utama dalam setiap lukisan. Artinya, jasa pembuatan lukisan sudah ditentukan perbuahnya. Biaya tambahan berupa konsumsi dan snack akan dipotong dari hasil pembuatan lukisan tersebut. Tipe kedua adalah pedagang, yaitu mereka yang mengumpulkan hasil lukisan dari para pelukis untuk kemudian diperdagangkan. Tipe ketiga adalah buruh lukis, yaitu mereka yang bekerja pada pengusaha lukisan (Suryatna, 1999: 109-111)
}

barang lokal. Akibatnya, masyarakat lebih banyak membeli produk asing daripada produk buatan Indonesia. Efek krisis moneter kemudian berimbas pula terhadap galeri lukis di Jelekong. Apabila masa sebelum krisis pembelian lukisan dalam 1 tahun dapat mencapai 10 hingga 20 buah dengan rata-rata harga lukisan sekitar 100.000 rupiah. Pada saat krisis moneter, jumlah 10 buah lukisan yang terjual saja sudah dianggap untung.

Penghasilan buruh tentu lebih kecil jika dibandingkan dengan penghasilan pelukis yang memiliki modal sendiri. Saat ini upah jasa seorang buruh lukis mengalami sedikit kenaikan, dari yang tadinya 1.200 rupiah -1.500 rupiah per lembar menjadi 2.000 rupiah per lembarnya. Buruh pelukis tersebut tidak mengenal kekurangan bahan lukis karena memang telah disediakan oleh sang empunya studio atau galeri. Dengan demikian, seluruh penghasilan sangat tergantung pada keaktifan buruh pelukis. Aep Saefuddin (34 th), misalnya, salah seorang pelukis yang mampu menyelesaikan 20 lukisan per harinya atau dengan rata-rata penghasilan sebesar 200.000 rupiah per-minggu. Walaupun demikian, mereka (pelukis yang memiliki modal sendiri) tetap saja merasa kurang sepadan dengan harga jual lukisan terutama apabila diborongkan.

Suryatna (1999: 122) mengatakan bahwa pada tahun 1990-an, harga lukisan borongan untuk satu kodi lukisan ukuran $50 \times 80 \mathrm{~cm}$ dihargai sebesar 95.000 rupiah. Jumlah sebesar itu apabila dikalkulasi dengan jumlah pengeluaran hanya mendapat keuntungan sebesar 1.500 rupiah untuk satu lukisan. Prinsip harga borongan adalah sama dengan ijon yang biasa dilakukan terhadap para petani, yaitu memberikan uang terlebih dahulu sebelum produk atau tanaman tersebut selesai dikerjakan (panen). Tentu saja harga yang dikenakan jelas lebih murah karena pemborong menerapkan sistem harga rugi yaitu harga jual sebenarnya dikurangi 
dengan persentase kerugian apabila ada hasil lukisan yang dianggap cacat. Persentase kerugian adalah mutlak hak sang pemborong sementara para pelukis hanya pasrah menyetujui saja karena terdesak oleh kebutuhan rumah tangga.

Keuntungan yang diperoleh pada tahun 1999 tersebut jauh di bawah keuntungan sebelum adanya krisis moneter. Pada tahun 1970 - 1980 satu buah lukisan dihargai kurang lebih 3.500 rupiah. Sebagai perbandingan, harga 1 gram emas kala itu adalah 500 rupiah. Dengan keuntungan sebesar itu, seorang pelukis selain dapat memenuhi kebutuhan rumah tangga juga dapat membeli kebutuhan yang bersifat sekunder bahkan tersier seperti sawah, barang elektronik, dan kendaraan bermotor. Dengan keuntungan yang dianggap cukup lumayan pada waktu itu, banyak para tetangga yang menyuruh anak-anaknya untuk belajar melukis. Setelah belajar dan mahir melukis, langkah selanjutnya adalah mencoba memasarkan hasil lukisannya. Keuntungan yang lumayan tersebut mulai terhambat setelah krisis moneter. Harga bahan baku yang meningkat pesat serta kurangnya daya beli masyarakat membuat penghasilan mereka turun drastis.

Beruntung pada tahun 1998 masih ada koperasi yang dirasa sangat membantu para pelukis, baik dalam pengadaan bahan baku maupun dalam hal penjualan lukisan. Terutama dalam penjualan, para pelukis kala itu merasa lebih baik menjualnya lewat koperasi karena keuntungan yang diperoleh jauh lebih besar daripada lewat pemborong atau tengkulak.

Saat ini koperasi tersebut dapat dikatakan sudah kurang begitu aktif karena sebagian besar para pelukis sudah memiliki galeri sendiri. Para pembeli dapat langsung membeli ke galeri tersebut ataupun dapat memesannya via telepon atau email. Jumlah galeri di Jelekong sekitar 20 buah dan pada setiap galeri ratarata memiliki pelanggan (dapat dikatakan) tetap - meski para pelanggan tidak mutlak hanya membeli lukisan pada satu galeri saja. Apalagi dengan mayoritas jenis lukisan yang sama (pemandangan) akan sangat sulit bagi pembeli memilih lukisan yang sangat menarik atau memiliki kekhasan tersendiri.

Selain memajang lukisan di galeri, adakalanya lukisan dipajang di trotoar. Jalan Braga dapat dianggap tempat memajang lukisan yang telah cukup lama dikenal oleh para pelukis Jelekong. Selain mencari pembeli "lokal", dengan memajang lukisan di Braga, bukannya tidak mungkin ada pembeli atau bahkan bandar lukisan dari luar negeri yang tertarik untuk membeli lukisan Jelekong. Menurut salah seorang pelukis ${ }^{3}$ yang memajang lukisannya di Jalan Braga mengatakan bahwa beberapa bandar lukisan luar negeri yang diketahuinya berasal dari negara Malaysia, Singapura, Timor-timur, dan Arab Saudi. Harga lukisan yang ditawarkan adalah 150.000 rupiah dalam bentuk lembaran (tanpa pigura). Setelah diberi pigura, harga tersebut akan melonjak drastis menjadi sekitar 500.000 rupiah per lukisan.

Gambaran harga lukisan sebesar 500.000 rupiah per buah jelas memberikan keuntungan yang sangat lumayan terutama bagi pemilik galeri. Hal ini memang demikian adanya karena pemilik galeri menentukan harga lukisan berdasarkan harga pasaran yang berlaku. Apabila pembelinya berasal dari luar negeri, maka harga lukisan jelas akan melambung tinggi karena disesuaikan dengan kurs mata uang negara. Salah satu contoh keberhasilan adalah galeri lukis di RT.V/RW.I, Kampung Jelekong milik Iim Nurhayati. Ia mempromosikan sekaligus memasarkan lukisan ke berbagai kota besar di Indonesia

\footnotetext{
3 Lihat lebih lanjut di "Jelekong, Kampung Pelukis di Bandung" Minggu, 16 Oktober 2011, bandung.blogspot.com/2011/10/belanjalukisan-di-bandung_16.html
} 
bahkan ke mancanegara. Hasil yang diperoleh adalah pesanan dari Magelang, Semarang, Bogor, Bandung, Bali, Malaysia, dan Arab Saudi. ${ }^{4}$ Berkat kerja keras memasarkan hasil lukisan dari galerinya tersebut, dalam sebulan lukisan yang terjual bisa mencapai 5.000 lukisan dengan keuntungan mencapai 100 juta rupiah. Keuntungan tersebut dipergunakannya untuk membeli rumah, mobil, dan untuk ibadah haji.

Kepemilikan galeri lukis memang memerlukan waktu yang tidak sedikit. Butuh pengetahuan tentang lukisan, strategi pemasaran, dan relasi yang cukup banyak agar galeri yang didirikan dapat terus bertahan terutama dalam menghadapi krisis moneter. Perihal krisis moneter yang telah dijelaskan di atas memang membuat tidak saja sentra lukis Jelekong yang terkena imbas tetapi juga sektor lain. Melewati krisis moneter adalah sebuah keberhasilan yang luar biasa. Meski untuk melewatinya sungguh sangat berat. Galeri G'art dan galeri milik Iim Nurhayati di atas jelas berdiri di atas kondisi keuangan Indonesia yang saat ini masih terpuruk. Namun demikian mereka tetap bertahan malah berhasil menumbuhkembangkan galeri mereka. Hal ini juga berlaku bagi pelukis sekaligus penjual seperti Adang Suheri (63 tahun) yang berhasil melewati krisis moneter (1997) dan hingga saat masih tetap menjual lukisannya di Jalan Braga. Pada era 80-an ia bisa meraup keuntungan 4.000.000 rupiah sebulan. Saat ini ia hanya bisa mengumpulkan 2.000.000

4 Para pembeli umumnya kurang begitu memahami lukisan dari segi artistiknya. Mereka lebih memandang lukisan dari sudut pandang keindahan atau sekedar hiasan rumah saja. Lebih lanjut lihat Gregorius Magnus Finesso dan Rini Kustiasih. 2010. "Menjual Seni, Mengepulkan Asap Dapur". dalam http://fitrahrahayu.blogspot.com/2010/01/menj ual-seni-mengepulkan-asap-dapur.html tanggal 29 Januari 2010. rupiah sebulan dari hasil penjualan lukisannya di Jalan Braga.

Selain dikenal sebagai sentra lukisan, Kampung Seni Jelekong juga telah lama didirikan galeri wayang golek, meskipun tidak sebanyak galeri lukisan. Salah satunya adalah G'art (Giriharja Art) yang didirikan oleh Djadjang Rukmana pada tanggal 3 September 2001. Galeri yang beralamat di Jalan Laswi No $145 \mathrm{Kp}$. Giriharja Kelurahan Jelekong Kec. Baleendah Kab. Bandung ini secara khusus menjual produk wayang golek dan berbagai merchandise wayang golek.

Wayang golek yang diperjualbelikan dibentuk dalam berbagai ukuran. Tokoh yang banyak mendapat perhatian dan menarik minat pembeli adalah dari golongan tokoh satria dan punggawa. Dua golongan tokoh tersebut dapat dikatakan sebagai golongan putih yang selalu membela kebenaran. Tokoh pembela kebenaran memiliki karakter gagah ditambah dengan berbagai kisah yang banyak menampilkan nama tokoh tersebut sedikit banyak telah sampai ke telinga pembeli awam. Terbukti dengan banyaknya pesanan wayang golek dari tokoh tersebut di antaranya Arjuna, Bima, Gatot Kaca, Rama, dan Shinta mulai dari ukuran mini sampai berukuran cukup besar (biasanya ditaruh pada sudut ruangan).

Kualitas pekerjaan pembuatan wayang golek memang diakui sangat lumayan sehingga mereka tidak segan-segan untuk mempromosikan sekaligus memasarkan hingga ke mancanegara. Beberapa negara yang menjadi langganan ekspor wayang golek produksi Jelekong adalah China dan Korea. Untuk setiap bulannya, mereka mengekspor sekitar 300 wayang golek berukuran mini.

Pasaran dalam negeri tentu saja tidak diabaikan karena merupakan tempat wayang golek lahir dan dibesarkan. Pesanan yang datang sangat lumayan. Menurut Muadz, di galeri tempatnya bekerja, dalam sebulan ia harus membuat 
sekitar 200 item wayang golek berukuran mini. Harga yang dipatok sekitar 100.000 rupiah per item. Dengan demikian, ia dapat meraup keuntungan sebesar 50.000.000 rupiah dalam sebulan.

Lain cerita Muadz, lain pula cerita Endhi. Ia yang memulai usaha sejak tahun 2008 dilatarbelakangi oleh selain keinginannya untuk melestarikan kebudayaan Sunda, tetapi juga ada segi keuntungan yang lumayan dari bisnis "benda budaya" tersebut. Berbeda halnya dengan Muadz, jenis wayang golek yang ditawarkan Endhi lebih variatif. Selain membuat wayang golek mini, ia juga membuat wayang golek berukuran raksasa, serta gantungan kunci berbentuk wayang golek. Promosi dilakukannya baik di dalam maupun di luar negeri. Negara yang membeli produk buatan Endhi di antaranya Kanada, Jerman dan Belanda. Ketiga negara tersebut membeli produk wayang golek berukuran mini. Harga yang dipatok untuk satu item wayang golek mini adalah 10.000 rupiah, sedangkan gantungan kunci sebesar 6.500 rupiah. Lain halnya dengan pembuatan wayang golek raksasa. Apabila berhasil terjual hingga ke luar negeri, satu item wayang golek berukuran raksasa tersebut dapat mencapai harga 50.000.000 rupiah.

Dede Rukmiarna (48 th), salah seorang pengrajin wayang golek juga menuturkan keuntungannya dari hasil penjualan wayang golek. Tokoh yang banyak diminati pembeli (dalam dan luar negeri) menurutnya adalah dari tokoh pandawa lima. Unsur warna yang dominan pada pandawa lima adalah merah, kuning, dan hijau. Ketiga warna tersebut memiliki karakter elegan dan ketegasan serta berpengaruh kuat pada sosok pandawa lima. Selain berhasil menjual ke pasaran dalam negeri, wayang golek buatannya ternyata banyak disukai oleh pembeli dari Jepang dan Inggris. Meskipun demikian, promosi terhadap budaya tradisional Indonesia (terutama wayang golek) tidak bersifat kontinyu sehingga trendsetter wayang golek tidak berkesinambungan di luar negeri. Hal ini berimbas pada proses penjualan menjadi tidak kontinyu.

Keuntungan yang diraih dalam bisnis penjualan wayang golek rupanya tidak berimbang dengan bisnis pertunjukan wayang golek. Pertunjukan wayang golek saat ini sudah jarang diminati masyarakat. Apabila ada pentas, itupun biasanya berasal dari kelompok wayang golek yang sudah mempunyai nama seperti grup wayang golek Putra Giri Harja III. Harga yang dipatok untuk sekali pertunjukan dapat mencapai belasan hingga ratusan juta rupiah. Walaupun tergolong cukup mahal, grup wayang golek Putra Giri Harja III mampu memikat sebagian besar masyarakat untuk datang dan menonton pertunjukan wayang golek tersebut. Daerah yang biasa mengundang grup wayang golek Putra Giri Harja III biasanya berasal dari Sukabumi, Subang, dan Kuningan.

Grup wayang golek Putra Giri Harja III dapat dikatakan sudah memiliki nama tidak hanya di dalam negeri, bahkan hingga ke luar negeri. Ketenaran padepokan wayang golek ini berhasil memikat sejumlah mahasiswa dari Perancis, Amerika Serikat, dan Vietnam untuk datang dan belajar tentang golek di padepokan wayang golek Putra Giri Harja III.

Kilas balik mengenai kesuksesan wayang golek baik dalam bentuk souvenir ataupun pertunjukan wayang golek rupanya memiliki sisi buram yang harus segera ditangani. Perihal pengrajin wayang golek ternyata masih memiliki kendala terutama dari segi regenerasi pengrajin wayang golek kurang berjalan dengan baik. Banyak kalangan usia produktif dari generasi muda kurang meminati usaha jenis ini. Hal ini tentunya harus mendapat perhatian pemerintah. Ketidakmauan kalangan muda untuk terjun dalam pembuatan wayang golek ini memang bukannya tanpa alasan. Profil wayang golek banyak dianggap oleh kalangan muda sudah ketinggalan zaman sehingga sangat berpengaruh terhadap animo 
mereka untuk terjun dalam bisnis wayang golek. Di samping itu, upah seorang pengrajin wayang golek cenderung relatif kecil. Otomatis kebutuhan pokok rumah tangga juga menjadi lebih sulit untuk dipenuhi, apalagi untuk memenuhi kebutuhan "ala" anak muda seperti handphone, fashion, bahkan kendaraan bermotor.

Para pengrajin wayang golek juga mengalami kendala pada masalah pendidikan. Rata-rata tingkat pendidikan pengrajin hanya sampai tingkat SLTP. Meskipun tingkat pendidikan tidak begitu berpengaruh namun dapat menjadi barometer yang berujung pada kesimpulan kasar bahwa untuk remaja yang hanya menyelesaikan pendidikannya pada tingkat pendidikan SLTP lebih berorientasi kerja. Alasan bekerja setelah lulus SLTP dilatarbelakangi oleh tingkat ekonomi yang rendah sehingga memaksa mereka melepas keinginan untuk melanjutkan sekolah ke jenjang pendidikan yang lebih tinggi.

Berdasarkan penghasilan yang diperoleh oleh para pelukis dan seniman wayang golek di Kelurahan Jelekong dapat dikatakan bahwa banyak dari pemilik galeri dan pengusaha produk lukisan dan wayang golek di Kelurahan Jelekong masih belum menerapkan standar upah minimum. Mereka bekerja dengan penghasilan yang diperoleh sesuai dengan jumlah hasil kerja mereka. Dan, setiap item hasil kerja mereka diberi upah yang apabila dirata-ratakan berada di bawah upah minimum. Hal ini memang sangat tergantung dari jenis usaha dan skala usaha. Jenis usaha kerajinan rakyat ratarata berskala industri rumah tangga. Oleh karena itu, untuk menggaji sesuai dengan upah minimum yang ditetapkan pemerintah adalah sangat sulit. Apalagi aliran produk mulai pembuatan hingga sampai ke tangan pembeli terkadang mengalami hambatan. Sifat jual beli yang tidak kontinyu tersebut sangat berpengaruh terhadap proses penggajian apabila berpatokan pada upah minimum. Kondisi demikian mau tidak mau harus dilakoni oleh seniman Jelekong yang secara langsung akan berdampak pada pemenuhan kebutuhan ekonomi rumah tangga.

\section{PENUTUP}

Pendapat - bisa jadi sebagai kesimpulan - yang dikemukakan oleh Suryatna (1999: 28) tentang Kesenian Jelekong adalah: (1) kesenian yang mempunyai pesan budaya; (2) memperlihatkan gaya (style) yang dimiliki bersama; (3) menggunakan media tertentu yang dapat merangsang pancaindra dan perasaan; dan (4) dibuat oleh orang yang memiliki kemahiran khusus sehingga menghasilkan suatu karya seni yang bersifat khas. Keempat hal tersebut memang benar adanya terhadap apa yang terjadi di Kampung Seni Jelekong. Gaya dan kemahiran yang diperoleh para seniman tersebut diperoleh - meski tanpa pendidikan khusus - melalui proses trial and error yang cukup lama sehingga mereka bisa berkarya dan sangat terasah dalam menuangkan karya seni mereka dengan sangat indah sehingga menggugah minat pengunjung untuk datang lagi ke Kampung Seni Jelekong.

Keberhasilan menciptakan sebuah karya seni terkadang tidak diimbangi dengan upah yang mereka terima. Kendala utama dari minimnya upah seniman Jelekong adalah jenis industri yang masuk dalam kelompok industri rumah tangga. Ketidakstabilan keuntungan yang diterima menjadi penyebab pola pengupahan berdasarkan jumlah hasil kerja. Dan, itupun untuk setiap item hasil kerja diberi upah yang tergolong sangat sedikit sehingga rata-rata hasil kerja mereka masih belum cukup untuk memenuhi kebutuhan rumah tangga, apalagi untuk mencapai taraf rumah tangga yang sejahtera.

Promosi, modal, kondisi keuangan negara, dan regenerasi menjadi kendala utama penyebab minimnya upah para seniman Jelekong. Promosi yang kurang 
gencar berdampak pada minimnya ketertarikan konsumen terhadap produk Jelekong. Modal untuk kategori industri rumah tangga sebenarnya sudah mencukupi namun hanya cukup untuk biaya produksi saja sementara biaya promosi kurang begitu diperhitungkan. Kondisi keuangan negara berdampak sangat buruk pada produk Jelekong. Krisis moneter mengakibatkan daya beli masyarakat terhadap produk Jelekong turun sangat drastis. Sementara kendala regenerasi bersifat relatif. Faktor ketinggalan zaman menurut penilaian generasi muda terhadap produk budaya sebenarnya bisa ditepis apabila upah yang diperoleh setara - ataupun lebih - dari upah minimum.

Penghasilan warga negara yang relatif kecil secara tidak langsung menjadi tanggung jawab pemerintah untuk segera ditangani. Karya seni Kelurahan Jelekong sebenarnya merupakan aset budaya yang memiliki prospek sangat besar karena mengubah image masyarakat terhadap stigma "kekunoan" terhadap produk budaya yang hingga saat ini masih berkembang dalam masyarakat. Selain itu, kreativitas merupakan sebuah unsur yang tidak akan habis digali dalam proses memberdayakan produk budaya menuju sebuah industri berbasis kebudayaan.

Keterkaitan antara industri dan kebudayaan seperti halnya yang dilakukan oleh para seniman di Kelurahan Jelekong jelas menjadi tanggung jawab Kementerian Perindustrian dan Perdagangan (Menperindag) dan Kementerian Kebudayaan dan Pariwisata (Kemenbudpar). Dua kementerian tersebut sudah seharusnya bekerja sama untuk memberdayakan kembali sisi kreativitas masyarakat yang memproduksi hasil karya budaya daerah. Sebuah langkah tegas yang harus segera dilaksanakan mengingat dua kementerian tersebut jauh tertinggal oleh para LSM yang telah lebih dahulu membantu para seniman di Kelurahan Jelekong.

\section{DAFTAR SUMBER}

Abdurachmat, Idris dan E. Maryani. 1998. Geografi Ekonomi. Bandung: Jurusan Pendidikan Geografi FPIPS IKIP. Bandung.

Andarina, Fika. 2006.

Kehidupan Masyarakat Pengrajin Bata Merah di Desa Mekarsari Kecamatan Ciparay. Bandung : Jurusan Pendidikan Geografi FPIPS UPI.

Colleta, J. Nat. 1975.

"Sebuah Pendekatan terhadap Antropologi Terapan di Indonesia". Dalam Kebudayaan dan Pembangunan. Jakarta: Yayasan Obor Indonesia.

Daldjoeni, N. 1997.

Geografi Baru Organisasi Keruangan dalam Teori dan Praktek. Bandung : Alumni.

Hidayat, Tiggana Nur. 2010.

Tinjauan Perubahan Bentuk Wayang Golek Panakawan Jelekong. Skripsi. Bandung: Fakultas Desain Universitas Komputer Indonesia

Ihromi, T.O (ed), 1996.

Pokok-pokok Antropologi Budaya, Jakarta: Yayasan Obor Indonesia.

Kamus Umum Bahasa Sunda. 1992

Koentjaraningrat, 1980.

Pengantar Ilmu Antropologi,

Jakarta: Aksara Baru 1996.

Pengantar Antropologi I. Jakarta: Rineka Cipta.

Kurniawan, I Made Ary. TT.

"Kampung Seni", dalam makalah.

ITB: Bandung. 
Makmur K., Ade. 2009.

"Metode Penelitian Kebudayaan", Makalah seminar Bimbingan Teknis Penelitian 2009. Balai Pelestarian Sejarah dan Nilai Tradisional Bandung: Bandung.

\section{Monografi Kelurahan Jelekong Kecamatan Baleendah Kabupaten Bandung Tahun 2009}

Monografi Kelurahan Jelekong Kecamatan Baleendah Kabupaten Bandung Tahun 2011

Naibaho, Roritskie H. 2009.

"Pembantu Rumah tangga (Studi Antropologi Perkotaan tentang Pembantu dan Majikan)", Skripsi, Medan: FISIP Universitas Sumatera Utara.

Priasukmana, Soetarso \& R. Mohamad Mulyadin. 2001.

"Pembangunan Desa Wisata : Pelaksanaan Undang-Undang Otonomi Daerah". Info Sosial Ekonomi Vol. 2 No.1

Putri, Vina Karina. 2011.
Kajian Historis Pertumbuhan Industri Kerajinan Seni Lukis Jelekong di Kabupaten Bandung Tahun 1968-2000. Skripsi. Bandung: UPI.

Rosyadi, dkk. 2009.

Pembuatan Wayang Golek di Kota Bogor. Bandung: BPSNT Bandung.

Sandi, I Made. 1985.

Geografi Regional Indonesia. Jakarta : UI

Soenyoto. Soeparman. 2008.

Pekerjaan dalam Dimensi Waktu. Yogyakarta: Syarikat.
Sumantri, Diaz. 2011.

Strategi Pengembangan Desa Wisata di Kelurahan Jelekong Kecamatan Baleendah Kabupaten Bandung. Skripsi. Bandung: UPI

Suryana, Jajang. 2002.

$\begin{array}{llll}\text { Wayang Golek } & \text { Sunda } & \text { Kajian } \\ \text { Estetika Rupa } & \text { Tokoh } & \text { Golek. } \\ \text { Bandung: Kiblat. } & & \end{array}$

Suryatna, Ayat. 1999.

"Menjadi Tukang Gambar: Studi tentang Proses Transmisi Kemampuan Menggambar pada Masyarakat Jelekong - Bandung", Tesis, Jakarta: Program Pascasarjana, Program Studi Antropologi, Universitas Indonesia.

Tarmidi, Lepi T., 1998.

"Krisis Moneter Indonesia: Sebab, Dampak, Peran IMF dan Saran", Revisi dan Updating Pidato Pengukuhan Guru Besar Madya pada FEUI, Jakarta, 10 Juni 1998.

Wahid, Abdurrahman. 1994.

"Fungsi Wayang", dalam Sinar Harapan Juni 1994, Jakarta. 